\title{
FROM LABORATORY EXPERIMENT TO LARGE SCALE APPLICATION - CASE STUDIES OF THE PHYTOREMEDIATION OF CHEMICAL AGENTS OF THE SLUDGE FIELDS AT KHARKIV WASTEWATER TREATMENT PLANT, UKRAINE
}

\author{
Nataliia Suchkova ${ }^{1}$ \\ Yuri Vergeles ${ }^{2}$ \\ ${ }^{2}$ Kharkiv National Academy of Municipal Economy, Ukraine \\ 'Wastewater Management Company (Kharkivkomunochystvod), Ukraine
}

\begin{abstract}
The contamination of the sewage sludge fields of municipal wastewater treatment plants (WWTPs) by heavy metals, hydrocarbons or other pollutants is a major environmental problem. Sludge can retain up to $96 \%$ of all the metals entering the WWTPs in sewage, therefore, when it is disposed to land, heavy metals will be accumulated in the soil. Effects of heavy metal accumulation are long lasting and even permanent. Phytotoxicity is the main problem, although metals can be transferred directly to man via vegetables and other crops or indirectly via animals, primarily cattle, eating herbage (zootoxic). The common metals in sludge are $\mathrm{Zn}, \mathrm{Cu}, \mathrm{Ni}, \mathrm{Pb}, \mathrm{Cr}$, and $\mathrm{Cd}$ which are generally the most toxic metal found in high concentration. Conventional treatment techniques of contaminated territory suffer from serious shortcomings which limit their applicability and efficiency. These include high cost and maintenance requirements, the need to transfer the contamination from one medium to another, and the extended duration of the operation. Alternatives to these treatments lie in insitu phytoremediation. Plants are among the most tolerant organisms to pollution, which emphasizes their utility for the detoxification or degradation of pollutants. The concept of phytoremediation was inspired by the discovery of hyper-accumulators, most of which belong to the botanical families Brassicaceae, Poaceae, Papilionaceae, Caryophyllaceae, and Asteraceae, which provide most of the candidates for heavy metal phytoremediation. Two other families are important - the Salicaceae with the genera Salix and Populus, which are effective against a range of pollutants; and the Betaceae which contribute species effective against salt ions and small (few rings) polycyclic aromatic hydrocarbons (PAHs). Some Asteraceae species have been shown to be good phytoremediants of radionuclide pollution [1].This paper summarizes the results obtained from laboratory, as well as from in-situ experiments (sludge fields at Kharkiv's WWTP, total area is approx. $126 \mathrm{ha}$ ) which focused on phytoremediation methodologies for the removal of heavy metals from sewage sludge.
\end{abstract}

\section{KEYWORDS}

Phytoremediation; Detoxification; Degradation; Heavy metals; Sewage sludge. 


\section{INTRODUCTION}

Kharkiv (1,500 thousand inhabitants) is the city located on a rolling plain in the Forest-Steppe zone in the North-Eastern Ukraine with developed industrial, scientific and cultural sectors. Mixed municipal and industrial wastewater is treated on the "Dikanivka" \& "Bezludivka" wastewater treatment plants. Further treatment of the sludge generated on both WWTP is carried out on the "Bezludivka" WWTP. Annual volume of sludge to be treated is more one million $\mathrm{m}^{3}$. Great volume of sewage sludge has been contaminated with toxic elements that were being accumulated for eighty years of the plant operation. Environment of the region has been affected rather seriously in result of out-of-date sludge dewatering system exploitation and heaps of dewatered sludge on the territory of the plant. Therefore, pollution of the soil, water and air in this region needs to be reduced, and where possible, eliminated [2].

Among the higher organisms, only plants have evolved effective strategies and mechanisms for survival in heavily polluted sites. They can thrive in environments contaminated to levels orders of magnitude greater that can be tolerated by other higher organisms. Plants cope with the presence of toxic metals in various ways, including their exclusion, their detoxification and their storage in specialized cells or cell compartments (vacuoles, cell walls) [8]. Two mechanisms for defense against heavy metal toxicity have been documented. One is based on the metallothioneins (Goldsbrough 2000) which are found in all living organisms; and the second on the synthesis of phytochelatins (Cobbett 2000, Rauser 1995), restricted to date to plants. The high capacity for the detoxification or degradation of pollutants shown by some plants species can be exploited for the emerging science of environmental biotechnology, termed phytoremediation. The concept of phytoremediation was inspired by the discovery of hyper-accumulators, most of which belong to the botanical families Brassicaceae, Poaceae, Papilionaceae, Caryophyllaceae, and Asteraceae, which provide most of the candidates for heavy metals phytoremediation. Two other families are important - the Salicaceae with the genera Salix and Populus, which are effective against a range of pollutants; and the Betaceae which contribute species effective against salt ions and small (few rings) polycyclic aromatic hydrocarbons (PAHs). Some Asteraceae species have been shown to be good phytoremediants of radionuclide pollution [1].

A particular feature of phytoremediation is its suitability for the removal of common gaseous pollutants, such as $\mathrm{CO}_{2}, \mathrm{NO}_{2}, \mathrm{CO}$ and $\mathrm{O}_{3}$, which is difficult to achieve by physical methods. The idea to rehabilitate sewage sludge fields at "Bezludivka" WWTP after its putting out from the operation using phytoremediation was appeared on the base of experience, received in Kalmar, Sweden in summer of 2006. There we took part in phytoremediation experiment focused on the ability of different plant species (from Brassicaceae and Fabaceae families) to remove PAHs from the contaminated soils. Furthermore, we consider phytoremediation methods as a low-cost and applicable on a large scale area.

\section{LABORATORY EXPERIMENT}

The first studies of dewatered sewage sludge on its physical, chemical and biological properties were carried out in the summer of 1998 and in the autumn of 2004. In 1998, sludge was analyzed on heavy metals contents and sanitary micro bacteriological properties; in 2004 - agrochemical properties and metal content. According to the results achieved the level of concentration of some metals $(\mathrm{Cu}, \mathrm{Ni}, \mathrm{Cr})$ in sewage sludge is essentially higher than its background concentration in the soil of Kharkiv region. Agricultural properties of sewage sludge need correction (organic matter content is not enough high; nitrogen content is too 
much; $\mathrm{pH}$ reaction is light acid). And bacteriological analyses showed that E.Coli concentration was under the limit [2].

The researches have been continuing since the autumn of 2006 with focusing of the attention on the sewage sludge fields' rehabilitation by phytoremediation. To organize large scale experiment in situ (at the sludge fields of "Bezludivka" WWTP) we with undergraduate students from Kharkiv National Academy of Municipal Economy (KNAME) have processed mini phytoexperiment at chemical laboratory of KNAME before. We divided experiment into two stages: sludge composting process and phytoremediation of the sludge. At the first stage (started $16^{\text {th }}$ of December 2006) we observed the effect of sludge digestion into the E.Coli and pathogen microorganisms' reduction and also humidity and weight reduction. At the second stage (started $21^{\text {st }}$ of April 2007) we aimed to identify naturally widespread plant species able to grow on contaminated areas and/or accumulate large amount of heavy metals, and which would be suitable candidates for phytoremediation purpose at large scale application in nearest future.

\subsection{Composting process}

Composting is nature's way of recycling. Composting biodegrades organic waste, i.e. food waste, manure, leaves, grass trimmings, paper, wood, crop, sewage sludge etc., and turns it into a valuable organic fertilizer [12].

Composting is a natural biological process, carried out under controlled aerobic conditions (requires oxygen). In this process various microorganism, including bacteria and fungi, break down organic matter into simpler substances. The effectiveness of the composting process is dependent upon the environmental conditions present within the composting system, i.e. oxygen, temperature, humidity, material disturbance, organic matter and the size and activity of microbial populations.

The essential elements required by the composting microorganism are carbon $(\mathrm{C})$, nitrogen $(\mathrm{N})$, phosphorous $(\mathrm{P})$, and potassium $(\mathrm{K})$. Microorganisms use carbon for both energy and growth, while nitrogen is essential for protein production and reproduction. The ratio of carbon to nitrogen is referred to as the $\mathrm{C}: \mathrm{N}$ ratio. An appropriate $\mathrm{C}: \mathrm{N}$ ratio usually ensures that the other required nutrients are present in adequate amounts.

Raw material blended to provide a $\mathrm{C}: \mathrm{N}$ ratio of $25: 1$ to $30: 1$ are ideal for active composting, although initial $\mathrm{C}: \mathrm{N}$ ratios from 20:1 up to 40:1 consistently give good composting results.

With the purpose to compost sludge before phytoremediation stage two kinds of samples of sludge were taken according to actual Ukrainian regulation [4]: dewatered sewage sludge from natural sludge fields (SF) and dewatered sewage sludge after mechanical centrifuges (SC) at "Bezludivka" WWTP. They were analyzed regarding organic matter, nutrients (general nitrogen and phosphate), humidity, heavy metals content and sanitary micro bacteriological properties. Then samples were put into eight laboratory glasses $(4 \mathrm{~L}$ in volume): 4 samples of SF and 4 samples of SC. Three glasses of each kind of sludge presented different $\mathrm{C}: \mathrm{N}$ ratio: 20:1, 30:1 and 40:1. The fourth glass of each kind of sludge presented natural attenuation. To make certain $\mathrm{C}: \mathrm{N}$ ratio we mixed different amount of leave wastes and sawdust with sludge. The combined $\mathrm{C}: \mathrm{N}$ ratio was calculated by using results of organic content and nutrients in the sludge and formula below: 
If we have one bag of SF (C:N=50:1), one bag of leave wastes $(C: N=8: 1)$ and one bag of sawdust $(C: N=8: 1)$ then combined we have $C: N$ ration of $(50: 1+8: 1+8: 1) / 3=(68: 1) / 3=22: 1$ $\approx 20: 1$ - the third glass.

At the second glass we mixed one bag of SF and one bag of sawdust, thus we had $\mathrm{C}: \mathrm{N}=30: 1$; we add three bags of SF and one bag of leave wastes to the third glass, so we had C:N $=40: 1$. In the same way we combined fifth, sixth and seventh glasses using other kind of sludge - SC. However the low $\mathrm{C}: \mathrm{N}$ ratio of $\mathrm{SC}(\mathrm{C}: \mathrm{N}=3: 1)$ did not give good composting results.

The duration of sludge composting process was approximately 4 months. During that period we have controlled the temperature, ${ }^{\circ} \mathrm{C}$ and humidity, $\%$ of the sludge. At the end of the first stage of the experiment sludge were analyzed on sanitary micro bacteriological properties and humidity.

\subsection{Phytoremediation}

Eight samples with composted sludge were put into eight pots. All experiment included fifteen pots. We added into experiment five samples of green compost from garden (control pots - C) and two samples of fresh sewage sludge: one is SF and another is SC (natural attenuation - NA). In all, nine plant species were tested, including Brassica napus, Medicago sativa, Trifolium pratense, Melilotus albus, Bromopsis inermis, Festuca sp., Lamium sp., Elytrigia repens, Achillea millefolium, featuring four main plant families (Brassicaceae, Poaceae, Asteraceae, Fabaceae). The choice among plant species was made on the base of experience received during the phytoremediation experiment in Kalmar, Sweden in the summer of 2006 .

\subsubsection{Brassicaceae}

Species of this family are among the best accumulators of heavy metals. It includes Brassica juncea, Sinapis alba, Alyssum and Thlaspi, which are known as hyper-accumulators, Brassica napus (or rapeseed). In the experiment the last one is used. The cultivation of oilseed rape on polluted sites can serve the double purpose of industrial production (biodiesel) and phytoremediation. Some disadvantages of using brassicas for phytoremediation are that measures need to be taken against insect damage, the dry leaf material is very fragile, and there is little interaction with symbiotic mycorrhizal fungi, the presence of which generally increases the level of tolerance to and uptake of heavy metals $[1,5,7,9]$.

\subsubsection{Poaceae}

The grass family is the one of the most important for the phytoremediation of heavy metal and organics such as the PAHs and petroleum hydrocarbons. An advantage of this family is that after cutting and drying, plant material is not fragile. Most species possess rather shallow root systems, but root density is high. In the experiment we used Festuca sp., taking into account pollution of the sludge fields' area by petroleum hydrocarbons and the circumstance that Festuca sp. was found in the sludge fields $[1,5,7,9]$.

\subsubsection{Fabaceae}

Many Fabaceae species are good phytoremediants of heavy metal pollution, while their leaf and bark waxes trap organic pollutants, and are effective for the stimulation of growth of rhizosphere microorganisms capable of PAHs and PCB degradation. The advantages of this 
group are their self-sufficiency in terms of nitrogen supply, and their favorable level of tolerance to drought. We used Medicago sativa and Melilotus albus $[1,5,7,9]$.

\subsubsection{Asteraceac}

Species of this family have been used for the bio-removal of heavy metals and radionuclides, such as $\mathrm{Sr}, \mathrm{Cs}$ and $\mathrm{U}$. In the experiment we usedeAchillea millefolium $[1,5,7,9]$.

During the phytoremediation period we have been controlled the following parameters of plants: germination tax, length of upper part and under part (root) and heavy metal content at the plants and sludge. This experiment was the mini-model of large scale experiment in-situ, which has been starting 27 of June 2007 at sewage sludge fields of "Bezludivka" WWTP [1, $5,7,9]$.

\section{IN-SITU EXPERIMENT (FIELD APPLICATION)}

The "Bezludivka" WWTP, situated near the southern border of the city of Kharkiv, has been operating since 1914 (Figure I). All territory of the plant is approximately 256 ha. The sludge fields are distributed over an area of about 126 ha. It has been constructed without impervious curtain, drainage system and with surface removal of separated water. Separated water and leachate from fields have cause for shallow water, groundwater and soil pollution. However

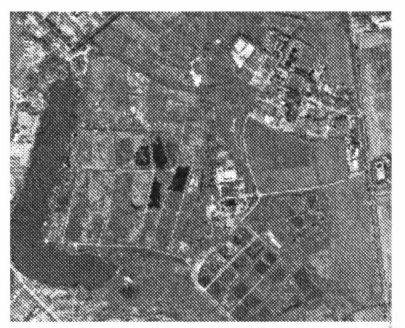

Figure l. Photo of the "Be-ludiva" WWTP, sewage sludge fields. mechanical system of sewage sludge dewatering with centrifuges "Westfalia-Separator" has been included in operation on the "Bezludivka" WWTP since 2004. Thus, putting out sludge fields from the operation of the plant with its further rehabilitation is possible at the present [2].

As continuation of mini phytoexperiment at chemical laboratory of KNAME we have been starting new large phytoexperiment in situ (sludge fields of "Bezludivka" WWTP) since $27^{\text {th }}$ of June 2007. The experimental site is $66 \mathrm{~m}^{2}$ and divided into six compartments. $32 \mathrm{~m}^{2}$ of them are used for phytoremediation and the rest is composted.

We have studied the uptake, translocation and distribution of some heavy metals, especially $\mathrm{Cu}, \mathrm{Ni}, \mathrm{Cr}$, by Brassica napus and Medicago sativa. Attention has been focused not only on the time course of uptake from the polluted site, but also on the level of tolerance of the plant to the certain environments.

During the experiment we have been controlled the following parameters of plants: germination tax, length of upper part and under part (root) and heavy metal content at the plants and sludge.

\section{RESULTS AND DISCUSSION}

The results of first mini phytoexperiment, which started $16^{\text {th }}$ of December 2006, are presented in Figure 2 and Tables $1-4$. 


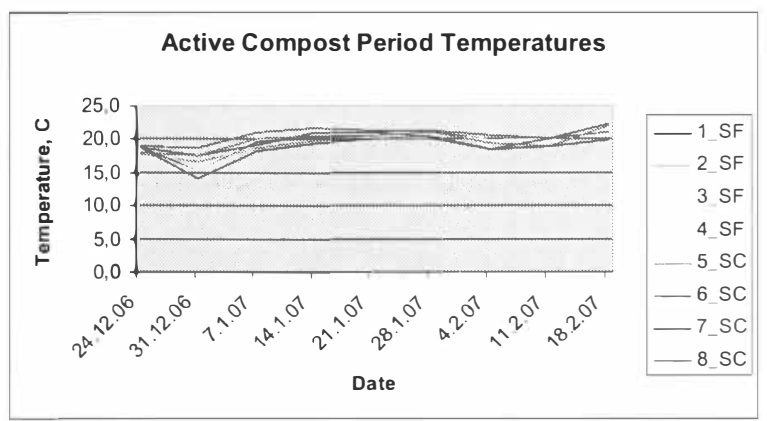

Figure 2. Compost temperature.

Temperature is directly proportional to the biological activity within the composting system. As the metabolic rate of the microbes accelerates the temperature within the system increases. Conversely, as the metabolic rate of the microbes decreases the system temperature decreases. Thus, the temperature is a good indicator of what is going on inside of the sludge [12]. Figure 2 shows slow and little increase of the temperature during several weeks. The value of temperature did not rich $30^{\circ} \mathrm{C}\left(22-25^{\circ} \mathrm{C}\right)$. However, good microorganisms activity should provide rapid increase of the temperature (to $45-60^{\circ} \mathrm{C}$ ). What is the reason of absence of temperature increase? Humidity, oxygen availability, $\mathrm{C}: \mathrm{N}$ ratio and microbial activity all influence temperature. If we focus our attention on the Table 2, we will see that initial humidity of the sludge was above $65 \%$. This limited air movement and possibly led to anaerobic conditions. The composting process under the anaerobic conditions is time consuming. Moreover, combined $\mathrm{C}: \mathrm{N}$ ratio of sludge (SC), leaves and sawdust was below 20:1 (C:N ratio of SC is $3: 1$ ), that is why the available carbon was fully utilized without stabilizing all of the nitrogen, which probably led to the production of excess ammonia and unpleasant odors. The results of bacteriological analyses before and after composting process are presented in Table 1. Pathogenic microorganisms and helmints are absent at the samples.

Table 1. Bacteriological indexes (E.coli) of the sludge before and after composting.

\begin{tabular}{|c|c|c|c|c|}
\hline \multirow{2}{*}{ The sample } & \multicolumn{2}{|c|}{ Initial data: } & \multicolumn{2}{|c|}{ Result data: } \\
\hline & MPN/I E.coli & UFC/I E.coli & MPN/I E.coli & UFC// E.coli \\
\hline $1 \mathrm{SF}$ & $<0.1$ & & 0.01 & $1 * 10^{5}$ \\
\hline $2 \mathrm{SF}$ & $<0.1$ & & 0.001 & $1 * 10^{6}$ \\
\hline $3 \mathrm{SF}$ & $<0.1$ & & 0.1 & $1 * 10^{4}$ \\
\hline 4 SF & $<0.1$ & & 0.1 & $1 * 10^{4}$ \\
\hline $5 \mathrm{SC}$ & 0.001 & & 0.0001 & $1 * 10^{7}$ \\
\hline $6 \mathrm{SC}$ & 0.001 & & 0.00001 & $1 * 10^{8}$ \\
\hline $7 \mathrm{SC}$ & 0.001 & & 0.01 & $1 * 10^{5}$ \\
\hline 8 SC & 0.001 & & 0.1 & $1 * 10^{4}$ \\
\hline
\end{tabular}


Kalmar ECO-TECH '07

KALMAR, SWEDEN, November 26-28, 2007

Table 2. Humidity of the sludge before and after composting.

\begin{tabular}{|l|r|r|}
\hline The sample & Initial humidity, $\%$ & Result humidity, $\%$ \\
\hline 1_SF & 76,43 & 48 \\
\hline 2 SF & 76,43 & 51,5 \\
\hline 3 SF & 76,43 & 45,5 \\
\hline 4 SF & 76,43 & 47,5 \\
\hline 5 SC & 77,23 & 71,4 \\
\hline 6 SC & 77,23 & 76,2 \\
\hline 7 SC & 77,23 & 76,5 \\
\hline 8 SC & 77,23 & 73 \\
\hline
\end{tabular}

The Table $I$ illustrates only three samples 3_SF, 4_SF and 8_SC are correspond to permissible limits of E.coli according to Ukrainian Regulations [4]. Probably absence of active composting of the sludge influenced on such kind of bacteriological results. However we have good results in the Table 2: the humidity of sludge from natural sludge fields (SF) has been reduced and consequently sludge has lost the weight. Sewage sludge after mechanical centrifuges (SC) is characterized complicated water-feedback, as it has high molecular organic substance - precipitator in content.

During the second stage of the experiment - phytoremediation (since 21.04.2007) we have been controlled germination tax, \% and length of upper part, $\mathrm{cm}$ of the plant species, cultivated on the sludge. The results are collected in the Table 3-4, Figure 3.

Table 3. Germination tax (\%).

\begin{tabular}{|c|c|c|c|c|c|c|c|c|c|c|c|c|c|c|c|c|c|c|}
\hline \multicolumn{2}{|c|}{ Day } & \multirow{2}{*}{$\begin{array}{l}\text { Plant } \\
\text { species }\end{array}$} & \multicolumn{15}{|c|}{ The sample } & \multirow[b]{2}{*}{$\mathbf{X}_{\text {average }}$} \\
\hline \multicolumn{2}{|c|}{\begin{tabular}{l|l} 
Date & No
\end{tabular}} & & $1 \mathrm{SF}$ & $2 \mathrm{SF}$ & $3 \mathrm{SF}$ & $4 \mathrm{SF}$ & $5 \mathrm{SC}$ & $6 \mathrm{SC}$ & $7 \mathrm{SC}$ & $8 \mathrm{SF}$ & $9 \mathrm{SF}$ & $10 \mathrm{sd} 1$ & C & $12 \mathrm{C}$ & $13 \mathrm{C}$ & $14 \mathrm{C}$ & $15 \mathrm{C}$ & \\
\hline \multirow{4}{*}{$\begin{array}{l}\text { Oे } \\
\stackrel{N}{ } \\
\dot{0} \\
\hat{N}\end{array}$} & \multirow{4}{*}{$6^{\text {th }}$} & $B$ & 0 & & \multirow{4}{*}{3,3} & \multirow[b]{4}{*}{0} & \multirow[t]{4}{*}{0} & \multirow{4}{*}{6,7} & \multirow{4}{*}{6,7} & \multirow[t]{4}{*}{ - } & NA & \multirow{4}{*}{$\begin{array}{l}\mathrm{NA} \\
\mathrm{NA} \\
\mathrm{NA} \\
\mathrm{NA}\end{array}$} & \multirow[t]{4}{*}{3,3} & \multirow{4}{*}{3,3} & \multirow{4}{*}{3,3} & \multirow[t]{4}{*}{$\because 6$} & \multirow{4}{*}{$\begin{array}{l}\text { NA } \\
\text { NA } \\
\text { NA } \\
\text { NA }\end{array}$} & 1,1 \\
\hline & & $M$ & 1 & 6,7 & & & & & & & NA & & & & & & & 5,5667 \\
\hline & & B/M/Bro & & & & & & & & & NA & & & & & & & 4,4333 \\
\hline & & Mix & $\mathbf{v}$ & & & & & & & & NA & & & & & & & 0 \\
\hline \multirow{4}{*}{ 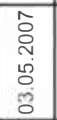 } & \multirow{4}{*}{$12^{\text {th }}$} & $B$ & \multirow{4}{*}{$\begin{array}{c}63,33 \\
1\end{array}$} & \multirow{4}{*}{33,33} & \multirow{4}{*}{46,7} & \multirow[b]{4}{*}{6,7} & \multirow[t]{4}{*}{93,33} & \multirow{4}{*}{20} & \multirow{4}{*}{46,7} & \multirow[b]{4}{*}{0} & NA & \multirow{4}{*}{$\begin{array}{l}\mathrm{NA} \\
\mathrm{NA} \\
\mathrm{NA} \\
\mathrm{NA}\end{array}$} & \multirow[t]{4}{*}{80} & \multirow{4}{*}{26,7} & \multirow{4}{*}{56,7} & & NA & 78,887 \\
\hline & & $M$ & & & & & & & & & NA & & & & & & NA & 26,677 \\
\hline & & $\mathrm{B} / \mathrm{M} / \mathrm{Bro}$ & & & & & & & & & NA & & & & & & NA & 50,033 \\
\hline & & Mix & & & & & & & & & NA & & & & & 6,7 & NA & 4,4667 \\
\hline 8 & & $B$ & 73,3 & & & & 80 & & & & NA & NA & 90 & & & & NA & 81,1 \\
\hline กิ & & $\mathrm{M}$ & & 33,3 & & & & 26,7 & & & NA & NA & & 30 & & & NA & 30 \\
\hline " & $18^{\text {th }}$ & $\mathrm{B} / \mathrm{M} / \mathrm{Bro}$ & & & 46,7 & & & & 60 & & NA & NA & & & 60 & & NA & 55,567 \\
\hline 8 & & Mix & & & & 10 & & & & 13,3 & NA & NA & & & & 10 & NA & 11,1 \\
\hline
\end{tabular}

Table 4. Length of upper part of the plants (cm).

\begin{tabular}{|c|c|c|c|c|c|c|c|c|c|c|c|c|c|c|c|c|c|c|}
\hline \multicolumn{2}{|c|}{ Day } & \multirow{2}{*}{\begin{tabular}{|l} 
Plant \\
species
\end{tabular}} & \multicolumn{15}{|c|}{ The sample } & \multirow[b]{2}{*}{$X_{\text {average }}$} \\
\hline Date & No & & $1 \mathrm{SF}$ & $2 S F$ & $3 \mathrm{SF}$ & $4 \mathrm{SF}$ & $5 \mathrm{SC}$ & $6 \mathrm{SC}$ & $7 \mathrm{SC}$ & $8 \mathrm{SF}$ & $9 \mathrm{SF}$ & \begin{tabular}{ll|l|l|l|}
10 & $\mathrm{SC}$ & 1 \\
\end{tabular} & $11 \mathrm{C}$ & $12 \mathrm{C}$ & $13 \mathrm{C}$ & $14 \mathrm{C}$ & $15 \mathrm{C}$ & \\
\hline \multirow{4}{*}{$\begin{array}{l}\hat{O} \\
\text { N } \\
\dot{0} \\
\text { ஸे }\end{array}$} & \multirow{4}{*}{$6^{\text {th }}$} & $B$ & - & & \multirow{4}{*}{0,5} & \multirow[b]{4}{*}{ - } & \multirow[t]{4}{*}{-} & \multirow{4}{*}{0,3} & \multirow{4}{*}{0,5} & \multirow{4}{*}{ 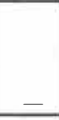 } & \multirow{4}{*}{$\begin{array}{l}\text { NA } \\
\text { NA } \\
\text { NA }\end{array}$} & \multirow{4}{*}{$\begin{array}{l}\text { NA } \\
\text { NA } \\
\text { NA }\end{array}$} & \multirow[t]{4}{*}{0,5} & \multirow{4}{*}{0,5} & \multirow{4}{*}{0,4} & & \multirow{3}{*}{$\begin{array}{l}\text { NA } \\
\text { NA } \\
\text { NA }\end{array}$} & 0,5 \\
\hline & & $\mathrm{M}$ & 1 & 0,5 & & & & & & & & & & & & & & 0,4333 \\
\hline & & $\mathrm{B} / \mathrm{M} / \mathrm{Bro}$ & $\downarrow$ & & & & & & & & & & & & & & & 0,4667 \\
\hline & & Mix & & & & & & & & & & & & & & & NA & - \\
\hline \multirow{4}{*}{$\begin{array}{l}\text { 今े } \\
\text { ते } \\
\text { Lे } \\
\ddot{8} \\
0\end{array}$} & \multirow{4}{*}{$12^{\text {th }}$} & B & 4,731 & \multirow{4}{*}{2} & \multirow{4}{*}{4,333} & \multirow[b]{4}{*}{4,5} & \multirow[t]{4}{*}{8,5} & \multirow{4}{*}{2,167} & \multirow{4}{*}{8} & \multirow[b]{4}{*}{ - } & NA & NA & \multirow[t]{4}{*}{3,5} & \multirow{4}{*}{2} & \multirow{4}{*}{3,5} & \multirow[b]{4}{*}{1,25} & NA & 5,577 \\
\hline & & $M$ & 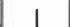 & & & & & & & & NA & NA & & & & & NA & 2,0557 \\
\hline & & B/M/Bro & & & & & & & & & NA & NA & & & & & NA & 5,2777 \\
\hline & & Mix & & & & & & & & & NA & NA & & & & & NA & 2,875 \\
\hline$\hat{\circ}$ & & $B$ & 4,731 & & & & 8,5 & & & & NA & NA & 3,457 & & & & NA & 5,5627 \\
\hline ำ & & $M$ & & 3,75 & & & & 4,25 & & & NA & NA & & 4 & & & NA & \\
\hline ஜุ & 18 & $\mathrm{~B} / \mathrm{M} / \mathrm{Bro}$ & & & 4,333 & & & & 8 & & NA & NA & & & 3,5 & & NA & 5,2777 \\
\hline 8 & & Mix & & & & 4,5 & & & & $\varepsilon$ & NA & $\mathrm{NA}$ & & & & 1,25 & NA & 4,5833 \\
\hline
\end{tabular}


Nomenclature: B - Brassica napus, M - Medicago sativa, Bro - Bromopsis inermis, Mix Trifolium pratense, Melilotus albus, Festuca sp., Lamium sp., Elytrigia repens, Achillea millefolium; 11_C...15_C - samples with green compost, control samples.

Table 3 demonstrates almost 100\% germination of Brassica seeds by the end of second week and late $30 \%$ germination of Medicago seeds. Among the mix of plant species only Trifolium pretense and Elytrigia repens were germinated. At the same time the better environment for Brassica seeds is in SF, then in SC and C. Table 4 shows length of upper part of the plants. The longer stems of plants are observed in SC samples.

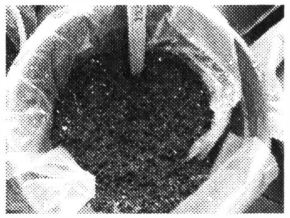

Day $6^{\text {th }}$

Brassica napus

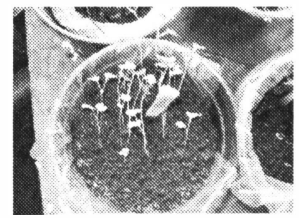

Day $12^{\text {th }}$

Brassica napus

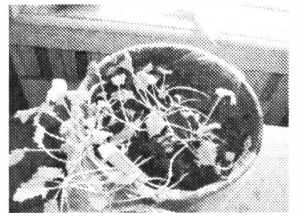

Day $18^{\text {th }}$

Brassica napus

Figure 3. Plant germination (1_SF).

By the $41^{\text {th }}$ day of the experiment the plants of 5_SC, 6_SC, 7_SC, 11_C, 13_C, 14_C still were germinating. Others have already died. One of the reasons of that could be drought. To restore experiment $14^{\text {th }}$ of June 2007 we planted new species at the samples (Brassica napus and Medicago sativa). The Table 5 and 6 content the data of germination tax and length of stem.

Table 5. Germination tax (\%).

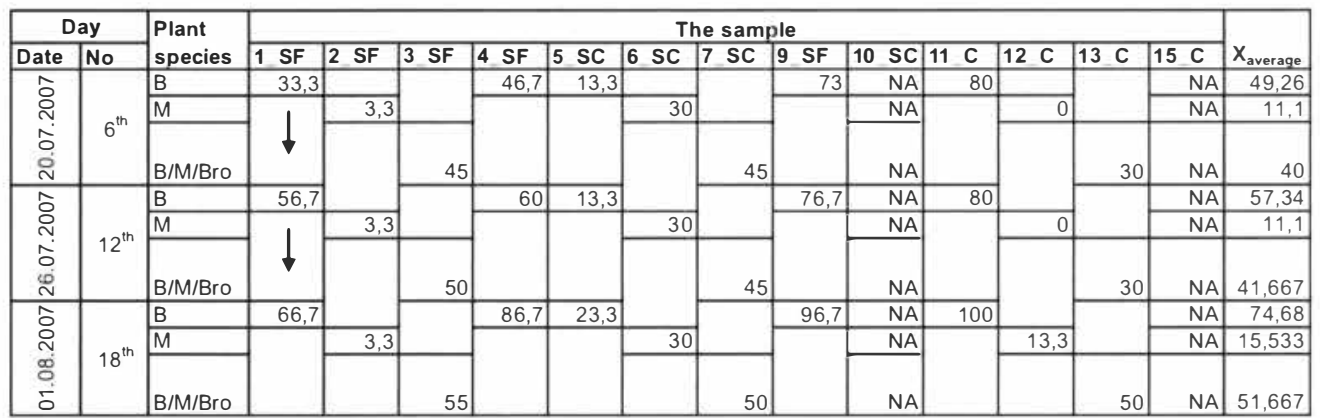


Table 6. Length of upper part of the plant (cm).

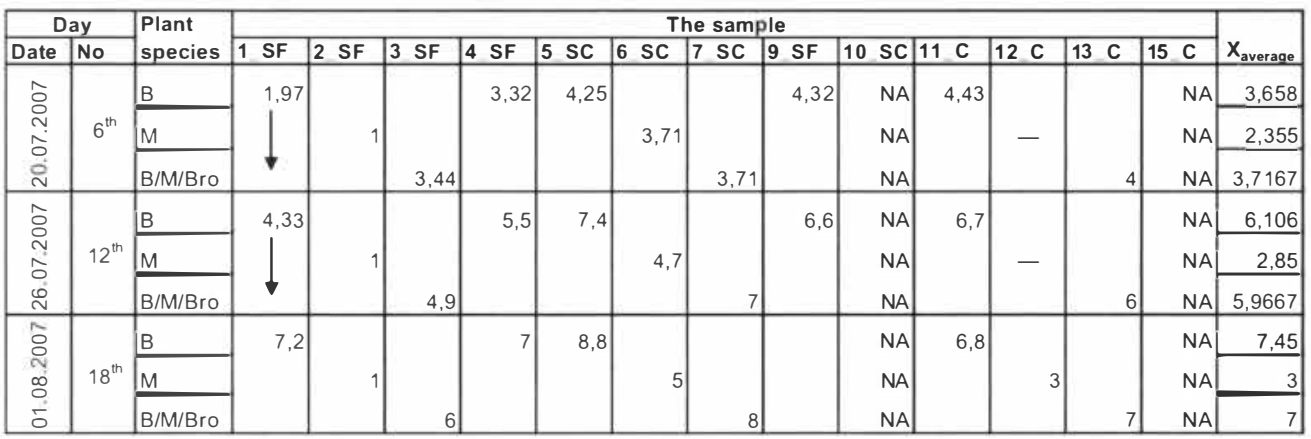

At the same time $27^{\text {th }}$ of June 2007 the phytoexperiment in situ at the sludge fields of "Bezludivka" WWTP have been starting. The results are collected in the Tables 7-8.

Table 7. Germination tax (\%).

\begin{tabular}{|c|c|c|c|c|c|c|c|c|c|}
\hline \multicolumn{2}{|c|}{ Day } & \multirow{2}{*}{$\begin{array}{l}\text { Plant } \\
\text { species }\end{array}$} & \multicolumn{6}{|c|}{ No of site } & \multirow{2}{*}{$\begin{array}{l}X_{\text {average }} \text { on the site } \\
24 \mathrm{~m}^{2}\end{array}$} \\
\hline Date & No & & 1 & II & \begin{tabular}{|l|l|} 
III \\
\end{tabular} & IV & $\mathrm{V}$ & $\mathrm{VI}$ & \\
\hline \multirow{3}{*}{11.07 .2007} & \multirow{3}{*}{$14^{\text {th }}$} & $\mathrm{M}$ & 0 & & & 0 & & & 0 \\
\hline & & $\mathrm{B} / \mathrm{M}$ & & 77 & & & 60 & & 68,5 \\
\hline & & $\mathrm{B}$ & & & 73 & & & 98 & 85,5 \\
\hline \multirow{3}{*}{02.08 .2007} & \multirow{3}{*}{$36^{\text {th }}$} & $M$ & 17 & & & 34 & & & 25,5 \\
\hline & & $\mathrm{B} / \mathrm{M}$ & & 60 & & & 60 & & 60 \\
\hline & & B & & & 60 & & & 98 & 79 \\
\hline \multirow{3}{*}{07.08 .2007} & \multirow{3}{*}{$41^{\text {th }}$} & $\mathrm{M}$ & 17 & & & 43 & & & 30 \\
\hline & & $\mathrm{B} / \mathrm{M}$ & & 69 & & & 60 & & 64,5 \\
\hline & & $B$ & & & 67 & & & 68 & 67,5 \\
\hline
\end{tabular}

Table 8. Length of upper part and under part of the plant $(\mathrm{cm})$.

\begin{tabular}{|c|c|c|c|c|c|c|c|c|c|c|c|c|c|c|c|c|}
\hline \multicolumn{2}{|c|}{ Day } & \multirow{3}{*}{$\begin{array}{l}\text { Plant } \\
\text { species }\end{array}$} & \multicolumn{12}{|c|}{ No of site } & \multirow{2}{*}{\multicolumn{2}{|c|}{$\begin{array}{l}X_{\text {average }} \text { on the stre } \\
24 \mathrm{~m}^{2}\end{array}$}} \\
\hline & & & & I & 1 & II & II & II & II & V & & V & & VI & & \\
\hline Date & No & & $\begin{array}{l}\text { upper } \\
\text { part }\end{array}$ & $\begin{array}{l}\text { root } \\
\text { area }\end{array}$ & $\begin{array}{l}\text { upper } \\
\text { part }\end{array}$ & $\begin{array}{l}\text { root } \\
\text { area }\end{array}$ & $\begin{array}{l}\text { upper } \\
\text { part }\end{array}$ & $\begin{array}{l}\text { root } \\
\text { area }\end{array}$ & $\begin{array}{l}\text { upper } \\
\text { part }\end{array}$ & $\begin{array}{l}\text { root } \\
\text { area }\end{array}$ & $\begin{array}{l}\text { upper } \\
\text { part }\end{array}$ & $\begin{array}{l}\text { root } \\
\text { area }\end{array}$ & \begin{tabular}{|l|} 
upper \\
part
\end{tabular} & $\begin{array}{l}\text { root } \\
\text { area }\end{array}$ & $\begin{array}{l}\text { upper } \\
\text { part }\end{array}$ & $\begin{array}{l}\text { root } \\
\text { area }\end{array}$ \\
\hline 11.07.2007 & $14^{\text {th }}$ & $\frac{\mathrm{M}}{\mathrm{B} / \mathrm{M}}$ & - & - & 5 & 3 & 6 & 3 & - & - & 5,5 & 4 & 6 & 4 & 5,625 & 3,5 \\
\hline 27.07 .2007 & $30^{\text {th }}$ & \begin{tabular}{|l|}
$\mathrm{M}$ \\
$\mathrm{B} / \mathrm{M}$ \\
$\mathrm{B}$ \\
\end{tabular} & 6 & 8 & & & 11 & 7 & 6 & 8 & & & 11 & 7 & 8,5 & 7,5 \\
\hline 07.08 .2007 & $41^{\text {th }}$ & \begin{tabular}{|l}
$\mathrm{M}$ \\
$\mathrm{B} / \mathrm{M}$ \\
$\mathrm{B}$
\end{tabular} & 8 & 5 & 12 & 5 & 13 & 7 & 7 & 5 & 11 & 5 & 19,4 & 6 & 11,7333 & 5,5 \\
\hline 2807.2007 & $60^{\text {th }}$ & \begin{tabular}{|l|}
$\mathrm{M}$ \\
$\mathrm{B} / \mathrm{M}$ \\
$\mathrm{B}$ \\
\end{tabular} & 15 & 8 & 12 & 4 & 10,67 & 6,3 & 14 & 6 & 21 & 7 & 13,38 & 5,75 & 14,3417 & 6,175 \\
\hline
\end{tabular}


Table 7 demonstrates approximately $80 \%$ germination of Brassica seeds and about $30 \%$ germination of Medicago seeds. The Medicago sativa seeds germinated up to the end of first month of the experiment in situ. The natural conditions were the following: outside temperaturee+35eC average, about 5 rains during the 60 experimental days. Approximately by the end of the first month $30 \%$ of germinated Brassica napus have died because of the hot weather and the rest of this specie have damaged with insect. The Medicago sativa proved their high level of tolerance to drought and insect. Table 8 shows that both Brassica napus and the Medicago sativa have long root system.

By the moment all samples of sludge and plants cultivated on this sludge from laboratory experiment and experiment in situ have been taken and are analyzing at the specialized laboratory on heavy metal content.

\section{CONCLUSIONS}

Our results show how phytoremediation can be applied to a practical situation, at least in the case of sewage sludge fields of municipal wastewater treatment plants. Our experiments have not yet finished by the moment, thus we do not know if plants remove metals from polluted sites. We expect that the technology is working, because for case of "Bezludivka" WWTP it is the best alternative as it cheap, easy and environmentally friendly method. When we receive the results of heavy metal content of sludge and plants, we will construct the realistic balance model of elements removal from polluted site and its carrying out to plant.

At the present we have some results of experiments, i.e. plant parameters. For example, the most limiting factor for Brassica napus germination is, probably, hot weather and insect. In future experiments we will take some measures against insect damage for this specie. Our general conclusion is: the experiment which is carrying out under proper conditions will give good expected results.

\section{ACKNOWLEDGEMENTS}

The stuff of Laboratory of microbiological problem of the Water and Wastewater Plants of Ukrainian Scientific and Research Institute "UkrVODGEO", Kharkiv Regional Sanitation Service, Chemistry Research Institute of Kharkiv National University by the name V. Karazin are all acknowledged for their support of the research, presented in the paper and Department of Technology of University of Kalmar, especially William Hogland and Marcia Marques, whose experience and knowledge in the current field helped to carry out the phytoexperiments in Kharkiv, Ukraine are also acknowledged.

\section{REFERENCES}

[1] Marmiroli, N., Samotokin, B., 2007. Advanced science and technology for Biological decontamination of sites affected by chemical and radiological nuclear agents/ NATO Science Seriesed IV. Earth and Environmental Science - Springer, 2007.

[2] Waste to energy, bioremediation and leachate treatment/ Proccedings of the Kalmar Eco-tech 2005: - Kalmar, Sweden, November, 2005.

[3] Communication from the Commission to the Council, the European parliament, the Economic and Social committee and the Committee of the Regions: Towards a Thematic Strategy for Soil. 
[4] TU 204 Ukraini 76-93 "Dobriva z osadiv stichnix vod" (Standard of Ukraine "Fertilizers are made from sewage sludge") - Kharkiv, 1994.

[5] Phytoremediation of Metal-Contaminated Soils /Proceedings of the NATO Advanced Study Institute: - Třešt, Czech Republic, August 2002.

[6] Morel, J.L. 2002. The Aims of the Remediation of Metal-Polluted Soils. Ibid.

[7] Schwartz, Ch., 2002. Behavior of hyper accumulator plants on metal-polluted soils phytoremediation. Ibid.

[8] Keller, C. 2002. Limitations and Technical Implications of Phytoextraction of Metals at Multi-Metals Contaminated Sites. Ibid.

[9] Dickinson, N., 2002. Phytoremediation of Industrial-Contaminated Sites Using Trees. Ibid.

[10] Svirenko, L., Vergeles, Ju., Jakovlev, V., 2003. Metals accumulation in soils and vegetation of river valleys in the city of Kharkiv, Ukraine. In: Abstracts book of the $2 \mathrm{~d}$ international conference "Soils of Urban, Industrial, Traffic and Mining Areas", July 911, Nancy, France, pp. 103-104.

[11] Korjakovsky, Yu., A. Nechaev. 20(05. Biological decontamination of sites affected by chemical and radioactive agents in Russia: an overview/ Proceedings of the NATO Advanced Study Institute: - Zhitomir, Ukraine, August 2005.

[12] Michael G. Pace, Bruce E. 2005. Miller "The composting process"/ Utah State University 